Erratum

\title{
HYPERHOMOCYSTEINEMIA LEAD TO TRANSMURAL INFLAMMATION OF COLON AND INCREASE SEVERITY OF DISEASE IN ACETIC ACID-INDUCED COLITIS IN RAT
}

\author{
LAMDA SOUAD ${ }^{1 *}$, NAIMI DALILA ${ }^{1}$, AGGOUN CHERIFA $^{2}$ \\ ${ }^{1}$ Ecole Nationale Superieure de Biotechnologie (ENSB), Nouveau Pôle Universitaire Ali Mendjeli, BP E66, 25100 Constantine, Algeria, \\ ${ }^{2}$ Animal Biology Departement, Faculty of Life Science and Nature, Frères Mentouri University, Constantine, Algeria \\ Email: souadlamda@gmail.com \\ Ref: http://www.ijppsjournal.com/Vol9Issue6/16036.pdf
}

\begin{abstract}
Objective: The present study was designed to evaluate the effect of hyperhomocysteinemia (Hhcy) induced by feeding rats high methionine diet on the colon wall. Colonic damages caused by Hhcy were compared with those induced by acetic -acid induced colitis.

Methods: Sprague-Dawley rats $(200-250 \mathrm{~g}$ ) were divided into four groups: group C (control), group M (received $1 \mathrm{~g} / \mathrm{kg}$ methionine p. o. during 15 d), group A (colitis was induced by transrectal administration of acetic acid 4\% on 8th day) and group MA (received methionine and acetic acid). At the end of the study, plasma homocysteine, C-reactive protein (CRP) and leukocytes (WBC) count were evaluated, all rats were sacrificed and distal $8 \mathrm{~cm}$ of the colon was dissected. Colon was weighed for disease activity index (DAI) and injuries were assessed macroscopically and histologically.

Results: High methionine diet induced significant $(\mathrm{P}<0.001)$ increase of homocysteine (hcy), CRP levels and WBC count compared to control. Acetic acid rats showed a significant decrease of WBC count. Mixed treatment caused a significant increase of hcy, CRP and a significant decrease of WBC count. Our results showed that Hhcy causes significant damages and immune cells infiltration in all layers of the colonic wall.

Conclusion: The present investigation demonstrated that Hhcy increased the major inflammatory markers as CRP and leukocytes count and produced transmural colitis in rats. Effect of Hhcy is more toxic on the colonic wall than acetic acid indeed while acetic acid lesions are localized in mucosa and submucosa the lesions of hcy extend to the all layers (mucosa, submucosa and muscularis propria). Acetic acid induced colitis in hyperhomocysteinemic rats increased the severity of colitis.
\end{abstract}

Keywords: Methionine, Hyperhomocysteinemia, Acetic acid, Inflammation, Colonic wall

\begin{tabular}{|c|c|c|c|c|}
\hline Section Page No. & $\begin{array}{l}\text { Line } \\
\text { No. }\end{array}$ & $\begin{array}{l}\text { Column } \\
1 / 2\end{array}$ & Uncorrected text & Corrected text \\
\hline $\begin{array}{l}\text { Abstract } \\
\text { p108 }\end{array}$ & 8 & & $\begin{array}{l}\text { Mixed treatment caused a significant } \\
\text { increase of hcy, CRP and a } \\
\text { significant decrease of WBC } \\
\text { count. }\end{array}$ & $\begin{array}{l}\text { Mixed treatment caused a significant increase of hcy, } \\
\text { CRP and WBC count }\end{array}$ \\
\hline $\begin{array}{l}\text { Results } \\
\text { Effects of high methionine } \\
\text { diet and acetic acid on } \\
\text { biochemical } \\
\text { and hematological } \\
\text { parameters } \\
\text { p } 109\end{array}$ & 2 & 2 & $\begin{array}{l}\text { Methionine supplementation was } \\
\text { found to increase plasma } \\
\text { levels of hcy, and CRP, in all treated } \\
\text { groups }(\mathrm{M} \text { and } \mathrm{MA}) \\
\text { compared to control group } \\
(\mathrm{p}<0.0001)\end{array}$ & $\begin{array}{l}\text { Methionine supplementation was found to increase } \\
\text { plasma levels of hcy, CRP and WBC count in all treated } \\
\text { groups (M and MA) compared to control group } \\
(\mathrm{p}<0.0001) .\end{array}$ \\
\hline $\begin{array}{l}\text { Results } \\
\text { Effects of high methionine } \\
\text { diet and acetic acid on } \\
\text { biochemical } \\
\text { and hematological } \\
\text { parameters } \\
\text { P } 109\end{array}$ & 5 & 2 & $\begin{array}{l}\text { Compared to the acetic } \\
\text { acid group }(\mathrm{A}) \text {, methionine-induced } \\
\text { significant increase of hcy } \\
(\mathrm{p}<0.001) \text { and CRP }(\mathrm{p}<0.001) \text { levels } \\
\text { in MA group. }\end{array}$ & $\begin{array}{l}\text { Compared to the acetic acid group (A), methionine- } \\
\text { induced significant increase of hcy, CRP levels and } \\
\text { WBC count }(p<0.001) \text { in M and MA groups. }\end{array}$ \\
\hline $\begin{array}{l}\text { Results } \\
\text { Effects of high methionine } \\
\text { diet and acetic acid on } \\
\text { biochemical } \\
\text { and hematological } \\
\text { parameters } \\
\text { P 109 }\end{array}$ & 6 & 2 & $\begin{array}{l}\text { Results } \\
\text { showed no significant increase of } \\
\text { hcy and CRP levels in MA when } \\
\text { compared to M. }\end{array}$ & $\begin{array}{l}\text { Results showed significant increase of WBC levels and } \\
\text { no significant increase of hcy and CRP levels in MA } \\
\text { when compared to M. }\end{array}$ \\
\hline $\begin{array}{l}\text { Results } \\
\text { Effects of high methionine } \\
\text { diet and acetic acid on } \\
\text { biochemical } \\
\text { and hematological } \\
\text { parameters } \\
\text { P } 109\end{array}$ & 7 & 2 & $\begin{array}{l}\text { Acid acetic induced no significant } \\
\text { increase of hcy } \\
\text { and CRP levels compared to control } \\
\text { (table 4). }\end{array}$ & $\begin{array}{l}\text { Acetic acid group induced significant decrease of WBC } \\
\text { count }(p<0.001) \text { and no significant increase of hcy } \\
(p=0.448) \text { and CRP }(p=0.081) \text { levels compared to } \\
\text { control. }\end{array}$ \\
\hline
\end{tabular}




\begin{tabular}{|c|c|c|c|c|c|}
\hline $\begin{array}{l}\text { Results } \\
\text { Effects of high metl } \\
\text { diet and acetic acid } \\
\text { biochemical } \\
\text { and hematological } \\
\text { parameters } \\
\text { P } 109\end{array}$ & onine & $8-14$ & 2 & $\begin{array}{l}\text { All groups showed } \\
\text { significant changes of WBC count } \\
(\mathrm{p}<0.001) \text { when compared to } \\
\text { control. While methionine increased } \\
\text { WBC count in M group, } \\
\text { acetic acid (A) and mixed treatment } \\
\text { (methionine and acid acetic: } \\
\text { MA) induced a decrease of WBC } \\
\text { count (p<0.001). } \\
\text { Results of MA group showed a } \\
\text { significant decrease of WBC } \\
\text { compared } \\
\text { to acetic acid control (A) and } \\
\text { methionine control (M) (table } 4)\end{array}$ & $\begin{array}{l}\text { The associated treatments methionine-acetic acid } \\
\text { showed significant increase of hcy, CRP and WBC count } \\
\text { (p?0.001) compared to control and A groups. (table 4) }\end{array}$ \\
\hline \multicolumn{6}{|l|}{ Results P 110} \\
\hline \multicolumn{4}{|c|}{ hcy } & CRP & WBC \\
\hline $\mathrm{C}$ & \multicolumn{3}{|c|}{$8.05 \pm 0.72$} & $0.02 \pm 0.01$ & $12.21 \pm 0.30$ \\
\hline M & \multicolumn{3}{|c|}{$47.20 \pm 2.89^{* * *}$} & $0.31 \pm 0.03^{* * *}$ & $15.35 \pm 0.45^{* * *}$ \\
\hline A & \multicolumn{3}{|c|}{$11.53 \pm 1.24$} & $0.09 \pm 0.01$ & $8.19 \pm 0.36^{* * *}$ \\
\hline MA & \multicolumn{3}{|c|}{$50.6 \pm 4.83^{* * *} \Upsilon \Upsilon \Upsilon$} & \multirow[t]{2}{*}{$0.33 \pm 0.07^{* * *} \Upsilon \Upsilon \Upsilon$} & $13.71 \pm 0.59 * * * \Upsilon$ \\
\hline ANOVA & \multirow{2}{*}{\multicolumn{3}{|c|}{192892}} & & 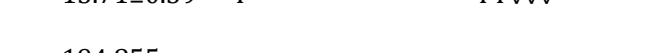 \\
\hline $\mathrm{F}$ & & & & 66.549 & 194.855 \\
\hline Df & \multicolumn{3}{|c|}{3.098} & 3.098 & 3.098 \\
\hline $\mathrm{P}$ & \multicolumn{3}{|c|}{ ? 0.00000} & 20.00000 & ?.0.0000 \\
\hline \multicolumn{6}{|c|}{$\begin{array}{l}\text { Data are expressed as mean } \pm \text { SEM of body weight change }(\%)(\mathrm{n}=6),{ }^{*} \mathrm{p}<0.05,{ }^{* *} \mathrm{p}<0.01,{ }^{* * *} \mathrm{p}<0.001 \text { when compared to C, } \Upsilon \mathrm{p}<0.05, \Upsilon \Upsilon \mathrm{p}<0.01, \\
\Upsilon \Upsilon \Upsilon \mathrm{p}<0.001 \text { when compared to A, } \diamond \mathrm{p}<0.05, \diamond \diamond \mathrm{p}<0.01, \diamond \diamond \diamond \mathrm{p}<0.001 \text { when compared to } M\end{array}$} \\
\hline \multicolumn{2}{|l|}{ Section page No. } & $\begin{array}{l}\text { Line } \\
n^{\circ}\end{array}$ & $\begin{array}{l}\text { Column } \\
1 / 2\end{array}$ & Uncorrected text & Corrected text \\
\hline \multicolumn{2}{|l|}{ Discussion } & 13 & 1 & significant increase of WBC count & significant decrease of WBC count \\
\hline \multicolumn{2}{|l|}{ Discussion } & 4 & 2 & $\begin{array}{l}\text { there was a significant decrease of } \\
\text { WBC count }\end{array}$ & there was a significant increase of WBC count \\
\hline
\end{tabular}

